\title{
Effect of moderate hydrostatic pressures on the enzymatic activity and bioactive composition of pineapple by-products
}

\author{
Diana I. Santos ${ }^{1}$ (1) | Carlos A. Pinto ${ }^{2}$ ( ) | Luiz C. Corrêa-Filho ${ }^{1}$ (๑) | \\ Jorge A. Saraiva ${ }^{2} \odot$ | António A. Vicente ${ }^{3} \odot$ | Margarida Moldão-Martins ${ }^{1}{ }^{1}$
}

${ }^{1}$ LEAF, Linking Landscape, Environment, Agriculture and Food, Instituto Superior de Agronomia, Universidade de Lisboa, Lisbon, Portugal

${ }^{2}$ QOPNA \& LAQV-REQUIMTE, Química Orgânica, Produtos Naturais e

Agroalimentares, Departamento de Química, Universidade de Aveiro, Campus Universitário de Santiago, Aveiro, Portugal

${ }^{3} \mathrm{CEB}$, Centre of Biological Engineering, University of Minho, Braga, Portugal

\section{Correspondence}

Margarida Moldão-Martins, LEAF,

Linking Landscape, Environment, Agriculture and Food, Instituto Superior de Agronomia, Universidade de Lisboa, Tapada da Ajuda, 1349-017 Lisbon, Portugal.

Email: mmoldao@isa.ulisboa.pt

\section{Funding information}

Fundação para a Ciência e a Tecnologia, Grant/ Award Numbers: SFRH/BD/109124/2015, SFRH/BD/137036/2018; National funding of FCT, Grant/Award Number: UID/ AGR/04129/2019; Centro de Engenharia Biológica, Grant/Award Number: UID/ BIO/04469/2019; QOPNA research Unit, Grant/Award Number: UID/QUI/00062/2019

\begin{abstract}
The application of abiotic stresses by moderate hydrostatic pressures (MHP) is still underdeveloped. Abiotic stresses allow activating the enzymatic complexes inducing the synthesis of de novo bioactive compounds. Pineapple by-products are rich in bromelain and bioactive compounds that can be enhanced through abiotic stresses. The aim of this study was to evaluate the effect of MHP on the enzymatic activity of pineapple by-products. Pineapple by-products were submitted to MHP (50-400 MPa between 1 and $15 \mathrm{~min}$ ) according to a central composite factorial design matrix. Samples were stored at $5 \pm 1^{\circ} \mathrm{C}$ for $24 \mathrm{hr}$, to allow enzymatic activity to occur. Enzymatic and antioxidant activities and total phenolic compounds (TPC) were quantified. MHP promoted a $262 \%$ increase in the phenylalanine ammonia-lyase activity and $36 \%$ increase in TPC, in shell samples. In core the activity of bromelain increased $350 \%$. These results pinpoint the potential to increase the value of pineapple by-products by enhancing the amounts of bioactive compounds through MHP application.
\end{abstract}

\section{Practical application}

Abiotic stresses can enhance enzyme activity, inducing the synthesis of bioactive compounds in living tissues. Hydrostatic pressure is an innovative nonthermal process that can be used to stabilize or increase enzymes' activity present in by-products generated in the minimally processed fruit and vegetables industry. Moderate hydrostatic pressure (MHP) act as abiotic stress inducing de novo phenols synthesis and enhancing bromelain activity. After treatment, enriched material could be stabilized and then blended with foods and beverages to improve nutraceutical properties and help in the prevention and treatment of chronic diseases. The study demonstrates that MHP (150-250 MPa) applied to the pineapple core and pineapple shell produce a phenolic and bromelain rich product.

\section{1 | INTRODUCTION}

Bioactive compounds' levels in fruits and vegetables can be enhanced by the application of controlled postharvest abiotic stresses, to induce de novo synthesis of active compounds. Different stresses can activate specific enzymes involved in the synthesis of the corresponding compound (Cisneros-Zevallos, 2003) and an increase in the activity of enzymes related with the biosynthesis and accumulation of secondary metabolites can be associated with late response of plants to abiotic stresses (Jacobo-Velázquez, González-Agüero, \& CisnerosZevallos, 2015).

Moderate hydrostatic pressure (MHP) can be used to stabilize or increase enzymes' activity and this enzyme activity enhancement is an effective response parameter with great potential for application in 
enzyme catalysis (Eisenmenger \& Reyes-De-Corcuera, 2009). The behavior of enzyme activity is variable: depending on the hydrostatic pressure applied and on the food matrix, the inactivation or activation of the enzyme may occur. Some studies reported increase of enzymatic activity in fruits and vegetables using MHP (Chakraborty, Kaushik, Rao, \& Mishra, 2014). The increase in enzyme activity after pressurization may occur due to the reversibility of the enzyme's conformation or reorganization of its active sites, modification of the substrate or of the medium properties, and/or displacement of the equilibrium towards the release of inhibitors from enzymes when enzyme-inhibitor complexes are formed (Eisenmenger \& Reyes-DeCorcuera, 2009). Once the enzyme is unfolded by pressure, it may become more sensitive to the substrate (Chakraborty, Kaushik, et al., 2014; Eisenmenger \& Reyes-De-Corcuera, 2009).

Enzymatic reactions in plant tissues can be enhanced by favoring the contact between the enzyme and the substrate, for example, caused by the disruption of tissue that occurs during stresses, particularly mechanical stresses such as application of hydrostatic pressure. Hydrostatic pressure may also alter the conformation of macromolecular substrates, increasing or decreasing the easiness of the catalytic action of the enzyme upon them, with this consequently affecting the enzyme-substrate interaction and, ultimately, enzyme activity (Cano \& Ancos, 2005).

Pineapple is a fruit that contains large amounts of proteolytic enzymes, namely stem bromelain (EC 3.4.22.32) and fruit bromelain (EC 3.4.22.33) that are homologous cysteine proteases (Raimbault, Zuily-Fodil, Soler, Mora, \& Cruz de Carvalho, 2013) which are absorbed by the body without losing proteolytic activity and without creating significant side effects. Bromelain has numerous advantages in the digestive and cardiovascular systems. Bromelain has anticancer properties, promotes apoptosis (cell death), relieves osteoarthritis, diarrhea and various cardiovascular disorders, and has also therapeutic benefits, such as for the treatment of angina pectoris, bronchitis, sinusitis, surgical trauma and thrombophlebitis, wound debridement, and absorption of drugs, principally antibiotics (Pavan, Jain, Shraddha, \& Kumar, 2012).

Phenylalanine ammonia lyase (PAL; EC 4.3.1.5) is very important in biosynthesis of phenolic compounds and can be induced by stress conditions. In the phenylpropanoid pathway, PAL is the first enzyme and plays an essential role in the biosynthesis of phenolic compounds in plants (Chen et al., 2006; Tomás-Barberán \& Espín, 2001). PAL is responsible for the catalysis of nonoxidative deamination of L-phenylalanine forming trans-cinnamic acid and a free ammonium ion. Plant cells were shown to increase the synthesis of PAL in response to hydrostatic pressure treatments stress, this resulting in an increase of the synthesis of polyphenols (Terefe, Buckow, \& Versteeg, 2014).

MHP may also increase or decrease the catalytic action of other important enzymes in plant tissues, such as pectin methyl esterase (PME; EC 3.1.1.11), polyphenol oxidase (PPO; E.C. 1.14.18.1), peroxidase (POD; EC 1.11.1.7) are usually very resistant to hydrostatic pressures (HP).

The by-products from fresh-cut fruit and vegetable industries are still physiologically active living tissues, able to synthetize compounds, and thus they can be used as biofactories of secondary metabolites with pharmaceutical and nutraceutical applications (Surjadinata \& Cisneros-Zevallos, 2012). The abiotic stresses can activate some enzymatic antioxidant systems of the fresh fruit and, consequently, enhance the antioxidant capacity (Cisneros-Zevallos, 2003). This study intends to evaluate the influence of moderate hydrostatic pressure treatments on the increase of enzymatic activity in pineapple byproducts and the corresponding effect on the accumulation of bioactive compounds by those tissues.

\section{2 | MATERIAL AND METHODS}

\section{1 | Reagents and solutions}

Folin-Ciocalteu reagent and cysteine $\left(\mathrm{C}_{3} \mathrm{H}_{7} \mathrm{NO}_{2} \mathrm{~S}\right)$ were purchased from Panreac AppliChem (Germany). 2,2-difenil-1-picrilhidrazil (DPPH; $\mathrm{C}_{18} \mathrm{H}_{12} \mathrm{~N}_{5} \mathrm{O}_{6}$ ), 2,4,6-tripyridyl-s-triazine (TPTZ; $\mathrm{C}_{18} \mathrm{H}_{12} \mathrm{~N}_{6}$ ), poly (vinylpolypyrrolidone) $\left(\mathrm{C}_{6} \mathrm{H}_{9} \mathrm{NO}\right)_{n}$, triton X-100 (t-Oct- $\mathrm{C}_{6} \mathrm{H}_{4}-\left[\mathrm{OCH}_{2} \mathrm{CH}_{2}\right]$ $x \mathrm{OH}, x=9-10)$, casein from bovine milk, glycine $\left(\mathrm{C}_{2} \mathrm{H}_{5} \mathrm{NO}_{2}\right)$, $\beta$-mercaptoetanol $\left(\mathrm{C}_{2} \mathrm{H}_{6} \mathrm{OS}\right)$, pectin from citrus peel (galacturonic acid $\geq 74 \%$ ), 2,2'-azinobis (3-ethylbenzothiazoline-6-sulphonic acid) diammonium salt (ABTS; $\mathrm{C}_{18} \mathrm{H}_{18} \mathrm{~N}_{4} \mathrm{O}_{6} \mathrm{~S}_{4}$ ) were acquired from SigmaAldrich (Germany). Trolox (6-hydroxy-2,5,7,8-tetramethylchroman2-carboxylic acid) was obtained from Acrós Organics (Belgium). Catechol $\left(\mathrm{C}_{6} \mathrm{H}_{6} \mathrm{O}_{2}\right)$, tyrosine $\left(\mathrm{C}_{9} \mathrm{H}_{11} \mathrm{NO}_{3}\right)$, L-phenylalanine $\left(\mathrm{C}_{9} \mathrm{H}_{11} \mathrm{NO}_{2}\right)$ and cresol red $\left(\mathrm{C}_{21} \mathrm{H}_{17} \mathrm{NaO}_{5} \mathrm{~S}\right)$ were purchased from Alfa Aesar (United Kingdom).

\section{2 | Sample preparation}

Pineapple by-products (Ananas comosus L.) were provided by company Campotec S. A. located in Torres Vedras, west center of Portugal. The shell $\left(9.27 \pm 0.60{ }^{\circ}\right.$ Brix $)$ and core $\left(10.17 \pm 0.67^{\circ}\right.$ Brix $)$ were stored under refrigeration $\left(4 \pm 1^{\circ} \mathrm{C}\right) \sim 18 \mathrm{hr}$ prior to packaging and abiotic stresses application. The by-products of the pineapple were cut in specific dimensions: core cylinders $(\sim 52.5 \times 30 \mathrm{~mm})$ and the shell $(\sim 110 \times 40 \mathrm{~mm})$. Subsequently, the by-products were packaged ( $\sim 40 \mathrm{~g}$ ) in PA/PE-90 (Alempack-Embalagens Flexíveis, Elvas, Portugal) that were vacuum sealed ( $85 \%$ of vacuum). The samples were prepared in triplicate for each treatment of the experimental design.

\section{3 | Moderate hydrostatic pressures treatment}

The packaged by-products were processed in a pilot-scale high hydrostatic pressure equipment (Hiperbaric 55, Burgos, Spain) with a $55 \mathrm{~L}$ vessel, according to a central composite factorial matrix (Tables 1 and 2), with the pressure conditions varying between 50 and $400 \mathrm{MPa}$ and the processing times between 1 and $15 \mathrm{~min}$. Samples were stored at $\pm 5^{\circ} \mathrm{C}$ for $24 \mathrm{hr}$ and then were frozen at $-80^{\circ} \mathrm{C}$ until the analyzes were performed. 


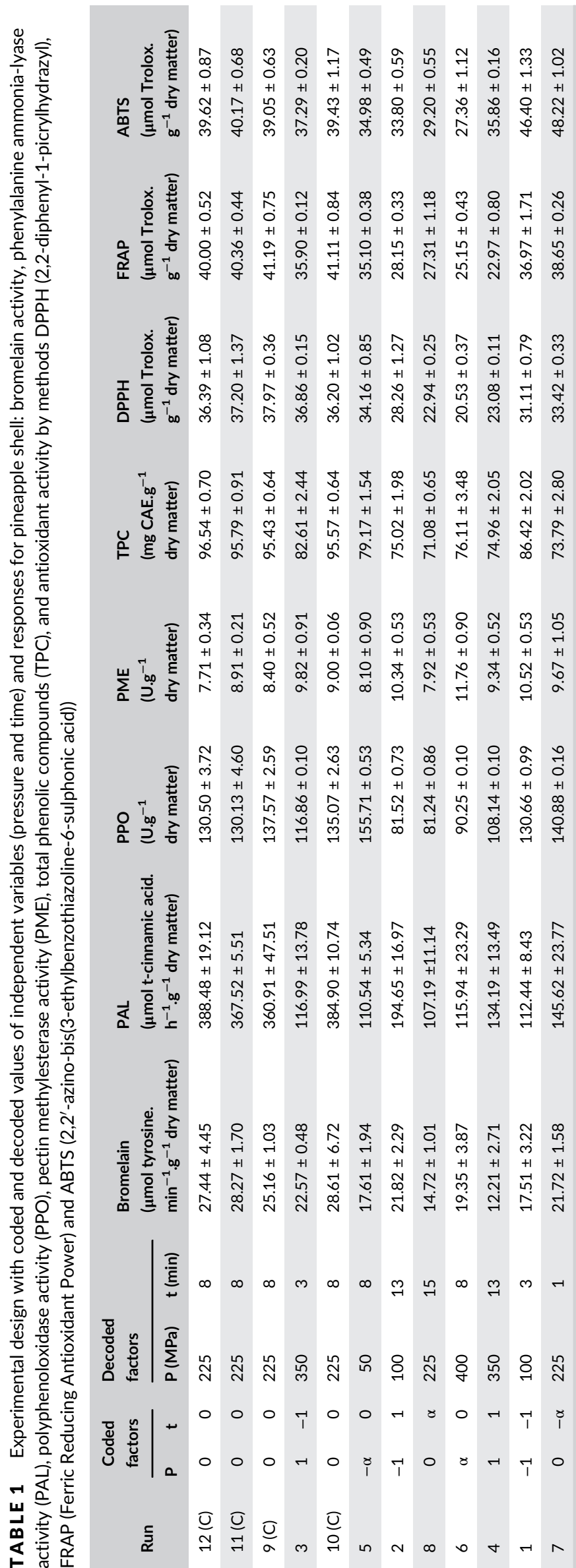

\subsection{Experimental design}

Response surface methodology (RSM) was used to find the most favorable experimental conditions. The experiments were carried out following a central composite rotatable design (CCRD), as a function of pressure (50-400 MPa) and time (1-15 min). A total of 12 experiments were carried out (Table 1-Shell and Table 2-core): four factorial design points $( \pm 1)$, four axial points $( \pm 1.414)$, and four central points (0). The repetition of the central point was used to determine the experimental error, which was assumed to be constant throughout the experimental domain. The experiments were performed randomly in order to avoid systematic errors.

The experimental data were statistically analyzed through a stepwise multiple regression analysis using StatisticaTM v.8 Software (StatSoft Inc., 2007), which was fitted to a second-order polynomial equation to predict each dependent variable [Enzymatic activity (Bromelain, PAL, PPO, PME), TPC, antioxidant activity (DPPH, FRAP, $A B T S)](Y)$. The three-dimensional response surface designs as a function of independent variables [pressure $\left(X_{1} ; \mathrm{MPa}\right)$ and time $\left.\left(X_{2} ; \mathrm{min}\right)\right]$, $b_{0}$ is the interception and $b_{i}, b_{j}, b_{i j}(i, j=1,2)$ are the linear, quadratic, and interaction coefficients, respectively that are described by the second order polynomial models, using decoded variables, as follows (Equation (1)).

$$
Y_{i}=b_{0}+b_{1} X_{1}+b_{2} X_{2}+b_{11} X_{1}^{2}+b_{22} X_{2}^{2}+b_{12} X_{1} X_{2}
$$

The adequacy of the model to the experimental data was confirmed by the analysis of variance (ANOVA) and coefficient of determination $\left(R^{2}\right)$ and adjusted $R^{2}$ (Adj- $R^{2}$ ) (Montgomery, 2017).

The desirability function was applied to experimental results to optimize multiple responses in RSM for shell samples: bromelain activity and phenylalanine ammonia-lyase (PAL) activity. This function is highly useful when optimizing complex systems (Corrêa-Filho, Lourenço, Duarte, Moldão-Martins, \& Alves, 2019).

\section{5 | Analytical methods}

The preparation of the pineapple extract for the enzymatic activities is described together with the quantification method. All experimental results were determined from extracts of the samples. Each extract was analyzed in triplicate and the average was used for each condition.

\subsection{1 | Bromelain activity}

The bromelain assay was determined according to Chakraborty, Rao, and Mishra (2014) with some modifications. Two grams of pineapple sample was mixed with $20 \mathrm{ml}$ extraction solution $(5 \mathrm{mmol} / \mathrm{L}$ ethylenediamine-tetra-acetic acid [EDTA] and $25 \mathrm{mmol} / \mathrm{L}$ cysteine prepared in $0.1 \mathrm{~mol} / \mathrm{L}$ sodium phosphate buffer $[\mathrm{pH} 8]$ ) in an ice bath for $2 \mathrm{~min}$ using an Ultra-Turrax (Ika Labortechnik T25 basic) at $8000 \mathrm{rpm}$. The mixture was centrifuged (Hermle Labortechnik Z $383 \mathrm{~K}$ ) at $8000 \mathrm{rpm}$ 


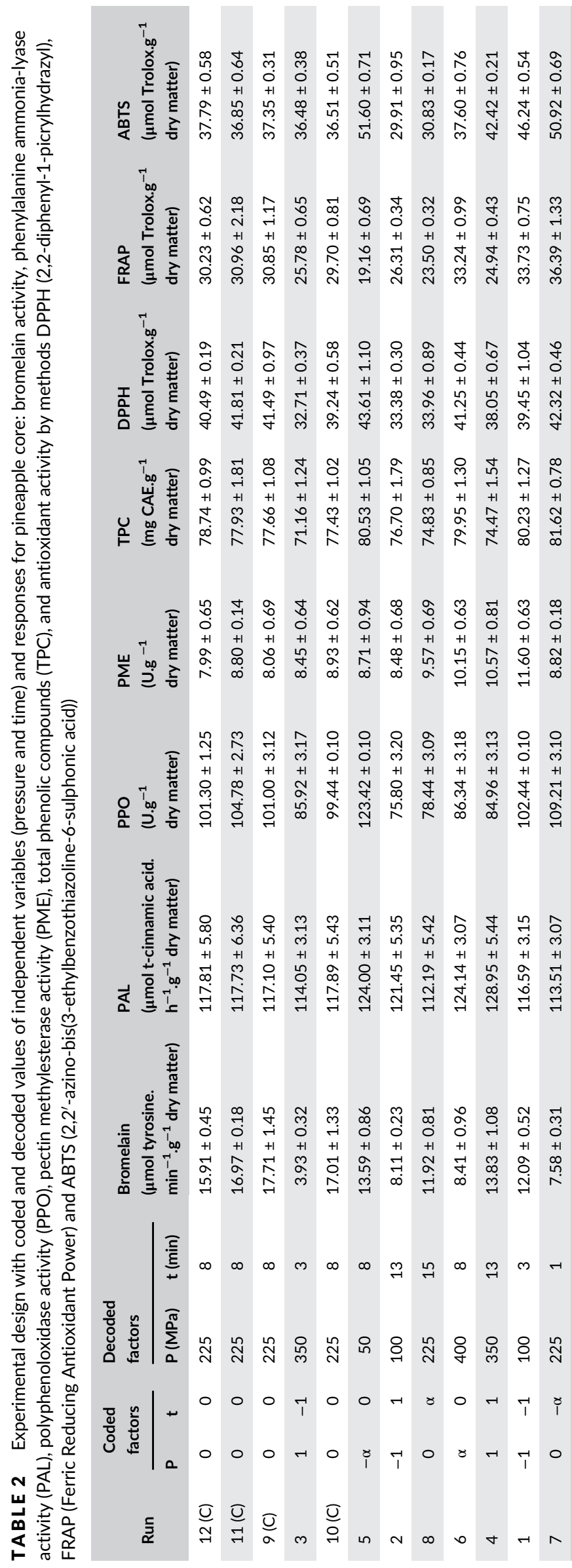

for $20 \mathrm{~min}$ at $4^{\circ} \mathrm{C}$ and the supernatant was filtered (Whatman no.1) and used as crude enzyme extract.

The reaction blend consisted of $50 \mu$ enzyme extract, $1,150 \mu \mathrm{l}$ of $1 \%$ (wt/vol) casein solution in $0.1 \mathrm{~mol} / \mathrm{L}$ glycine and $25 \mathrm{mmol} / \mathrm{L}$ cysteine. The mixture was incubated in a shaking water bath (10 $\mathrm{min}$ at $37^{\circ} \mathrm{C}$ ) and the reaction was subsequently stopped by adding $1.8 \mathrm{ml}$ of $5 \%$ (wt/vol) trichloroacetic acid (TCA). The assay mixture was filtrated $(0.45 \mu \mathrm{m})$ and the absorbance was taken at $280 \mathrm{~nm}$ (UNICAM UV/Vis Spectrometer). In the blank sample, TCA was added before the addition of casein substrate. Bromelain activity was calculated using a standard curve established with tyrosine (0-50 mg/L), and expressed as the amount of tyrosine on a dry weight basis and reported in the units $\mu \mathrm{mol}$. $\mathrm{min}^{-1}$. $\mathrm{g}^{-1}$ (dry weight basis).

\subsection{2 | Phenylalanine ammonia-lyase activity}

The phenylalanine ammonia-lyase (PAL) activity determination was performed as described in Alegria, Gonçalves, Moldão-Martins, Cisneros-Zevallos, and Abreu (2016) with few modifications. The pineapple sample $(2 \mathrm{~g})$ was added to $2 \mathrm{~g}$ polyvinylpolypyrrolidone and homogenized with $20 \mathrm{ml}$ of $50 \mathrm{mmol} / \mathrm{L}$ borate buffer $(\mathrm{pH} \mathrm{8.5)} \mathrm{con-}$ taining $\beta$-mercaptoethanol $(400 \mu \mathrm{l} / \mathrm{L})$. This mixture was kept into an ice-bath and homogenized in an Ultra-Turrax for $2 \mathrm{~min}$ at $8000 \mathrm{rpm}$. Homogenates were centrifuged at $8000 \mathrm{~g}$ for $20 \mathrm{~min}$ at $4^{\circ} \mathrm{C}$ and the supernatant collected, filtered (Whatman no.1) and used as crude enzyme extract.

The PAL reaction mixture was performed by addition $2000 \mu \mathrm{l}$ of the borate buffer, $600 \mu \mathrm{l}$ of $\mathrm{L}$-phenylalanine $(100 \mathrm{mmol} / \mathrm{L})$ substrate solution and $400 \mu$ of crude enzyme extract. The blank reactions were prepared as described using nanopure water as a substitute L-phenylalanine $(100 \mathrm{mmol} / \mathrm{L})$ substrate solution. The samples were read before and after $1 \mathrm{hr}$ of incubation in bath water $\left(40^{\circ} \mathrm{C}\right)$ in a spectrophotometer at $290 \mathrm{~nm}$ after being blanked with borate buffer. The PAL activity was expressed as the amount of synthesized $\mathrm{t}$-cinnamic acid on a dry weight basis and reported in the units $\mu \mathrm{mol}$. $\mathrm{h}^{-1} \cdot \mathrm{g}^{-1}$ (dry weight basis).

\subsection{3 | Polyphenol oxidase activity}

The extraction of polyphenol oxidase (PPO) followed a modified method of Zhou, Dahler, Underhill, and Wills (2003). The sample material ( $2 \mathrm{~g}$ ) was homogenized with $20 \mathrm{ml} 0.1 \mathrm{~mol} / \mathrm{L}$ sodium phosphate buffer at $\mathrm{pH} 6.5$ at $4{ }^{\circ} \mathrm{C}, 10 \%$ polyvinylpolypyrrolidone (wt/wt) and Triton $\mathrm{X}-100$ for $2 \mathrm{~min}$ in an Ultra-Turrax at low speed $(8,000 \mathrm{rpm})$ in an ice-bath to avoid excess heating and to prevent protein denaturation. The homogenate was then centrifuged at $8000 \mathrm{rpm}$ for $20 \mathrm{~min}$ at $4^{\circ} \mathrm{C}$ and filtered (Whatman no.1). The supernatant was used for PPO activity assay.

PPO activity was assayed spectrophotometrically by a modified method based on Babu, Rastogi, and Raghavarao (2008). The assay mixture consisted in $2.5 \mathrm{ml}$ of substrate solution $(50 \mathrm{mmol} / \mathrm{L}$ catechol 
in $0.1 \mathrm{~mol} / \mathrm{L}$ phosphate buffer, $\mathrm{pH}$ 6.5) and enzyme extract to a final reaction volume of $3.0 \mathrm{ml}$. The rate of catechol oxidation was followed at $420 \mathrm{~nm}$ for $1 \mathrm{~min}$. An enzyme activity unit was defined as the amount of the enzyme that causes an increase of 1.0 in absorbance per minute per milliliter ( $\Delta$ Abs. $\mathrm{min}^{-1} \cdot \mathrm{g}^{-1}$ ) (dry weight basis).

\subsection{4 | Pectin methylesterase activity}

The pectin methylesterase (PME) activity was assayed according to Chakraborty, Rao, and Mishra (2014) and Pinheiro, Silva, Alegria, Abreu, and Gonçalves (2012), with some modifications. PME from the pineapple samples $(2 \mathrm{~g}$ ) was extracted using $20 \mathrm{ml} 1.5 \mathrm{~mol} / \mathrm{L}$ sodium chloride solution and was mixed with homogenizer during $2 \mathrm{~min}$ at low speed $(8,000 \mathrm{rpm})$ in an ice-bath. The mixture was centrifuged at $8000 \mathrm{~g}$ for $20 \mathrm{~min}$ at $4^{\circ} \mathrm{C}$, and the supernatant was filtered (Whatman no.1) and adjusted to the $\mathrm{pH} 8.8$ with $\mathrm{NaOH} 1$ and $0.1 \mathrm{~mol} / \mathrm{L}$. The reaction mixture contained $2,600 \mu \mathrm{l}$ pectin from citrus fruits $(0.5 \%)$, $150 \mu \mathrm{l} \mathrm{cresol}$ red (0.01\%) in sodium phosphate buffer at $0.003 \mathrm{~mol} / \mathrm{L}$ and $\mathrm{pH} 8.8$, and $250 \mu \mathrm{l}$ enzyme extract. The absorbance was measured at $573 \mathrm{~nm}$ during $1 \mathrm{~min}$. The definition used for 1 unit (U) of enzyme activity was the amount of enzyme that produced a change in absorbance of 1.0 per min per $g$ of sample $\left(\Delta\right.$ Abs.min ${ }^{-1} \cdot \mathrm{g}^{-1}$ ) (dry weight basis), under assay conditions.

\subsection{5 | Pineapple extract preparation for TPC and antioxidant activity}

The pineapple extract preparation was evaluated following the procedure of Heredia and Cisneros-Zevallos (2009) and Swain and Hillis (1959), with some modifications. The extracts preparation was carried out in a ratio of 1:10 (wt:vol) of three pineapple by-products independent sample and methanol (100\%) followed by Ultra-Turrax homogenizer at $8000 \mathrm{rpm}$ for $2 \mathrm{~min}$. The homogenates were incubated overnight $(12-24 \mathrm{hr})$ at $4^{\circ} \mathrm{C}$. The extracts were obtained by centrifugation at $8000 \mathrm{rpm}$ for $20 \mathrm{~min}\left(4^{\circ} \mathrm{C}\right)$, and the supernatants were stored at $4^{\circ} \mathrm{C}$, protected from light until analysis.

\section{\begin{tabular}{l|l}
2.5 .6 & TPC
\end{tabular}}

The TPC were determined according Heredia and CisnerosZevallos (2009), and Swain and Hillis (1959), with some modifications. The $150 \mu$ l extract aliquots were diluted with 2,400 $\mu$ l nanopure water, followed by $150 \mu \mathrm{l}$ of $0.25 \mathrm{~mol} / \mathrm{L}$ Folin-Ciocalteu and incubated for $3 \mathrm{~min}$ at room temperature. The reaction was stopped by adding $300 \mu \mathrm{l}$ of $1 \mathrm{~mol} / \mathrm{L} \mathrm{Na}_{2} \mathrm{CO}_{3}$ and the mixture was incubated for $2 \mathrm{hr}$ protected from light. The supernatant samples were read at $725 \mathrm{~nm}$ absorbance. The total phenolics for each sample was determined by using a standard curve developed with equivalent chlorogenic acid (CAE) and expressed as $\mathrm{mg} C A E / \mathrm{g}^{-1}$ dry weight.

\subsection{7 | Antioxidant activity (DPPH assay)}

The antioxidant capacity by DPPH (2,2-diphenyl-1-picrylhydrazyl) method was evaluated following the procedure of Brand-Williams, Cuvelier, and Berset (1995) with some modifications. The DPPH solution was prepared with methanol until reaching 1.1 units of absorbance at $515 \mathrm{~nm}$. The sample extracts were prepared as described above. The sample $(100 \mu l)$ were taken from the supernatants and then added with a 3,900 $\mu \mathrm{l}$ DPPH solution. This mixture was homogenized, and the reaction occurred for $40 \mathrm{~min}$ in the dark. Subsequently, the samples were read in a spectrophotometer at $515 \mathrm{~nm}$. The blank was prepared with methanol and used as a control. The antioxidant activity was determined using Trolox for the standard curve (100 to $1,500 \mu \mathrm{mol} / \mathrm{L}$ ), and the results were expressed by the Trolox Equivalent Antioxidant Capacity (TEAC [ $\mu \mathrm{mol} / \mathrm{g}$ ] [dry weight basis]).

\subsection{8 | Antioxidant activity (FRAP assay)}

The FRAP (Ferric Reducing Antioxidant Power) assay was performed according to Benzie and Strain (1996) with some modifications. Initially the preparation of several solutions including $300 \mathrm{mM}$ acetate buffer $\left(3.1 \mathrm{~g}\right.$ sodium acetate $\left[\mathrm{C}_{2} \mathrm{H}_{3} \mathrm{NaO}_{2} \cdot 3 \mathrm{H}_{2} \mathrm{O}\right]$ and $16 \mathrm{ml}$ glacial acetic acid $\left.\left[\mathrm{C}_{2} \mathrm{H}_{4} \mathrm{O}_{2}\right]\right), \mathrm{pH} 3.6,10 \mathrm{mmol} / \mathrm{L}$ TPTZ (2,4,6-tripyridyl-s-triazine) solution in $40 \mathrm{mmol} / \mathrm{L} \mathrm{HCl}$, and $20 \mathrm{mmol} / \mathrm{L} \mathrm{FeCl}_{3} \cdot 6 \mathrm{H}_{2} \mathrm{O}$ solution. The working solution was prepared by mixing $35 \mathrm{ml}$ acetate buffer $300 \mathrm{mmol} / \mathrm{L}, 3.5 \mathrm{ml} \mathrm{TPTZ}$ solution, and $3.5 \mathrm{ml} \mathrm{FeCl} \cdot 6 \mathrm{H}_{2} \mathrm{O}$ solution. The reaction started with the mixture of $2.7 \mathrm{ml}$ of the FRAP solution, $270 \mu \mathrm{l} \mathrm{H}_{2} \mathrm{O}$ and $90 \mu \mathrm{l}$ the extract samples and then warmed in water bath at $37^{\circ} \mathrm{C}$ for $30 \mathrm{~min}$. The colored product (ferrous tripyridyltriazine complex) were read at $595 \mathrm{~nm}$ using water as blank. The antioxidant capacity was calculated using a standard curve established with Trolox and the results are expressed as TEAC.

\subsubsection{Antioxidant activity (ABTS-assay)}

Antioxidant activity was measured using ABTS (2,2'-azino-bis (3-ethylbenzothiazoline-6-sulphonic acid)) method as described by Re et al. (1999) and Rufino et al. (2007) with some modifications. Two stock solutions of $A B T S(7 \mathrm{mmol} / \mathrm{L})$ and potassium persulfate $(140 \mathrm{mmol} / \mathrm{L})$ were prepared. The working solution was prepared by mixing $2 \mathrm{ml}$ of ABTS solution with $35.2 \mu$ of potassium persulfate solution and keeping it in the dark at room temperature for 12-16 hr. The ABTS solution was then diluted with methanol to obtain an absorbance of $0.700 \pm 0.05$ at $734 \mathrm{~nm}$. The reaction was performed by mixture $2,970 \mu \mathrm{l}$ ABTS solution with $30 \mu \mathrm{l}$ sample aliquots, during $6 \mathrm{~min}$ and the absorbance at $734 \mathrm{~nm}$ was immediately recorded. The absorbance of the reaction samples was compared to the Trolox standard and the results were expressed in terms TEAC. 


\section{RESULTS AND DISCUSSION}

\section{1 | General discussion}

The experimental results of response variables [Enzymatic activity (Bromelain, PAL, PPO, PME), TPC, antioxidant activity (DPPH, FRAP, ABTS)] are shown in Tables 1 and 2 for pineapple shell and core, respectively. Regression analysis was performed in order to statistically evaluate the quadratic models developed. Table 3 shows the linear and quadratic effects of the independent variables, as well as their interaction, on responses for each studied dependent variable. Determination coefficients, $R^{2}$ and Adj- $R^{2}$ and significance of lack of fit are also presented. Just the models with a determination coefficient $\left(R^{2}\right)$ higher than 0.75 , indicating a good fit to the experimental data, are presented (Haaland, 1989).

\section{2 | Bromelain activity}

The quadratic models generated for bromelain activity in the pineapple shell and core were significant in fitting of the experimental data within a confidence level of $95 \%$. High values for $R^{2}$ and $A d j-R^{2}$ (Table 3) indicated a good fit to the data. Furthermore, the adequacy of the second-order polynomial models was confirmed by the not significant lack of fit $(p>.05)$.

From Table 3, linear and quadratic terms of pressure and time, as well as their interaction, were significant on the response models for bromelain activity in both pineapple shell and core samples. The effect of linear terms was positive whereas the effect of quadratic terms was negative. The interaction of the variables pressure and time had a positive effect in the bromelain activity of the pineapple core and negative effect in the activity of the bromelain in pineapple shell.

Figure 1 exhibits the prediction of bromelain activity as a function of pressure (MPa) and time ( $\mathrm{min}$ ) of the MHP treatment, based on the regression models developed for shell (a) and core (b). The figures, convex surfaces, show that bromelain tends to increase with increasing time and pressure, but at higher pressures (>300 MPa) the enzyme activity decreases due to partial inactivation. The moderate hydrostatic pressure (200-250 MPa) and treatment time (5-10 min) promoted the increase of $134 \%$ in bromelain activity in pineapple shell and $350 \%$ in pineapple core. The optimal pressure and time conditions for the enzymatic activity of bromelain were $235.5 \mathrm{MPa}$ and $6.74 \mathrm{~min}$ for the pineapple shell and $211 \mathrm{MPa}$ and $8.7 \mathrm{~min}$ for the pineapple core samples.

A moderate pressure between 100 and $300 \mathrm{MPa}$ has a protective effect against thermal denaturation of fruit bromelain at temperatures $\left(30-70^{\circ} \mathrm{C}\right)$, while inactivation rate decrease with increasing pressure at a given temperature (Chakraborty, Rao, \& Mishra, 2016b).

Fruit bromelain resistance in crude extract depends on its structure, and homology differs between eight diverse isoforms with a wide molecular weight range that exhibit an additional stability of this enzyme during processing with HP (Bhattacharyya, 2008; Chakraborty et al., 2016b).

The increase in bromelain activity can be explained by the formation of enzymes through different biosynthesis pathways due to the defense mechanism of plant tissues when subjected to stress, or leaching of enzymes from other cell compartments after pressurization (Orozco-Cardenas, Narvaez-Vasquez, \& Ryan, 2001).

In other studies, the residual activity of bromelain in pineapple puree increased firstly and subsequently decreased (Chakraborty, Rao, \& Mishra, 2016a). Enzyme activity presented the same behavior

TAB LE 3 Regression coefficients of second-order polynomial equations for each decoded response variable [P - pressure (MPa) and $t$ - time (min)]: bromelain activity, phenylalanine ammonia-lyase activity (PAL), polyphenoloxidase activity (PPO), total phenolic compounds (TPC), and antioxidant activity by methods DPPH (2,2-diphenyl-1-picrylhydrazyl), FRAP (Ferric Reducing Antioxidant Power) and ABTS (2,2' -azino-bis (3-ethylbenzothiazoline-6-sulphonic acid))

\begin{tabular}{|c|c|c|c|c|c|}
\hline Parameter & $\begin{array}{l}\text { Pineapple } \\
\text { sample }\end{array}$ & Equation & $\mathbf{R}^{2}$ & $R^{2}$ adj & Lack of fit \\
\hline \multirow[t]{2}{*}{ Bromelain activity (BRM) } & Shell & $\begin{array}{l}\mathrm{BRM}=-5.613+0.173 \mathrm{P}^{*}-0.0003 \mathrm{P}^{2^{*}}+3.847 \mathrm{t}^{*}- \\
\quad 0.183 \mathrm{t}^{2^{*}}-0.006 \mathrm{Pt}^{*}\end{array}$ & 0.95 & 0.91 & Not significant \\
\hline & Core & $\begin{array}{l}\mathrm{BRM}=6.453^{*}+0.038 \mathrm{P}^{*}-0.0002 \mathrm{P}^{2^{*}}+1.513 \mathrm{t}^{*}- \\
\quad 0.154 \mathrm{t}^{2^{*}+0.006 \mathrm{Pt}^{*}}\end{array}$ & 0.97 & 0.95 & Not significant \\
\hline $\begin{array}{l}\text { Phenylalanine ammonia-lyase } \\
\text { activity (PAL) }\end{array}$ & Shell & $\begin{array}{l}\mathrm{PAL}=-390.908^{*}+3.825 \mathrm{P}^{*}-0.008 \mathrm{P}^{2^{*}}+84.169 \mathrm{t}^{*}- \\
\quad 4.823 \mathrm{t}^{2^{*}}-0.026 \mathrm{Pt}\end{array}$ & 0.97 & 0.94 & Not significant \\
\hline Total phenolic compounds (TPC) & Shell & $\begin{array}{l}\text { TPC }=52.069^{*}+0.209 \mathrm{P}^{*}-0.0005 \mathrm{P}^{2^{*}}+5.871 \mathrm{t}^{*}- \\
\quad 0.424 \mathrm{t}^{2^{*}}+0.002 \mathrm{Pt}\end{array}$ & 0.93 & 0.86 & Significant \\
\hline Antioxidant activity (DPPH) & Shell & $\begin{array}{l}\text { DPPH }=15.669+0.140 P^{*}-0.0003 P^{2^{*}}+2.680 t^{*}- \\
\quad 0.155 t^{2^{*}}-0.004 P t\end{array}$ & 0.86 & 0.74 & Significant \\
\hline Antioxidant activity (FRAP) & Shell & $\begin{array}{l}\text { FRAP }=21.884^{*}+0.150 \mathrm{P}^{*}-0.0004 \mathrm{P}^{2^{*}}+1.990 \mathrm{t}- \\
\quad 0.161 \mathrm{t}^{2^{*}}-0.002 \mathrm{Pt}\end{array}$ & 0.97 & 0.95 & Significant \\
\hline
\end{tabular}

${ }^{*} p<.05$. 
FIGURE 1 Response surfaces fitted for bromelain activity as a function of pressure (MPa) and time ( $\mathrm{min}$ ) treatment: (a) pineapple shell and (b) pineapple core (a)

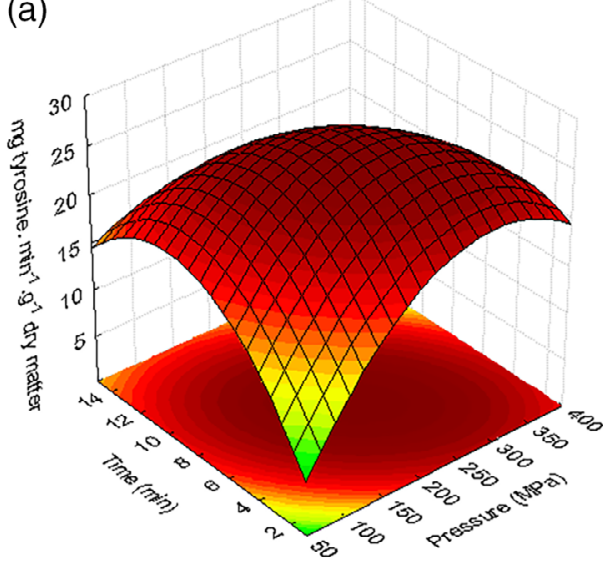

(b)

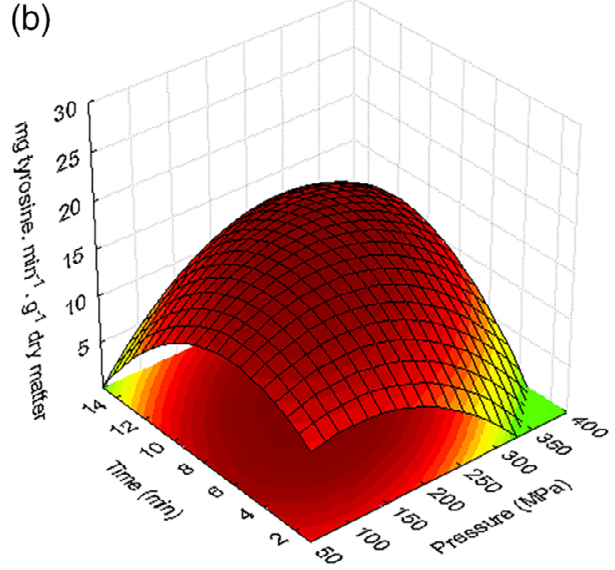

during storage time ( 45 days at $4^{\circ} \mathrm{C}$ ) of avocado paste and mango pulp (Jacobo-Velázquez \& Hernández-Brenes, 2010).

\section{3 | PAL activity and TPC}

The second-order polynomial model generated for PAL activity of the shell samples presents a good fit to the data $\left(R^{2}=0.97\right.$ and Adj$R^{2}=0.94$ ) and a not significant lack of fit (Table 3). The effect of linear terms was positive whereas the effect of quadratic terms was negative, as well as the effect of the interaction of the variables.

Model obtained for TPC presents a good fit to the data $\left(R^{2}=0.93\right.$ and $\operatorname{Adj}-R^{2}=0.86$ ) but a significant lack of fit (Table 3 ), so these results will be considered only as indicative of a trend. The significance of each individual, interactive, and quadratic terms towards the TPC is the same observed for the PAL activity.

The response surface presented in Figure 2 shows that the PAL activity of the shell samples showed an increase for the treatments at higher pressures (150-300 MPa) and longer dwell times (5-10 min), despite a decrease occurs for higher pressures (> $300 \mathrm{MPa}$ ) and very long times (> $12 \mathrm{~min}$ ). Pineapple shell samples showed an increase in the enzymatic activity of PAL (262\%) and, consequently, an increase of TPC (36\%), compared with the raw material (Table 1). Moderate pressures (150-300 MPa) and time treatment (5-10 min) also seems to increase the content of TPC.

The pineapple shell presented optimum conditions of pressure and time for the enzymatic activity of PAL at 221.5 MPa and $8.14 \mathrm{~min}$.

Regarding pineapple core, models obtained for PAL activity and TPC present an insufficient fit to the data $\left(R^{2}<0.75\right)$ and a correspondingly significant lack of fit and thus are not presented. PAL activity and TPC in pineapple core increased average 15 and $14 \%$, respectively, in relation to raw material (Table 2). In stressed samples the enzymatic activity of PAL ranged between 112.19 and $128.95 \mu \mathrm{mol}$ t-cinnamic acid. $\mathrm{h}^{-1} \cdot \mathrm{g}^{-1}$ dry matter and TPC values ranged between $71.16-81.62 \mathrm{mg} \mathrm{CAE} \cdot \mathrm{g}^{-1}$ dry matter in the pineapple core samples.

PAL is an important enzyme in the phenylpropanoid pathway that has an important role in the secondary metabolism of plants,

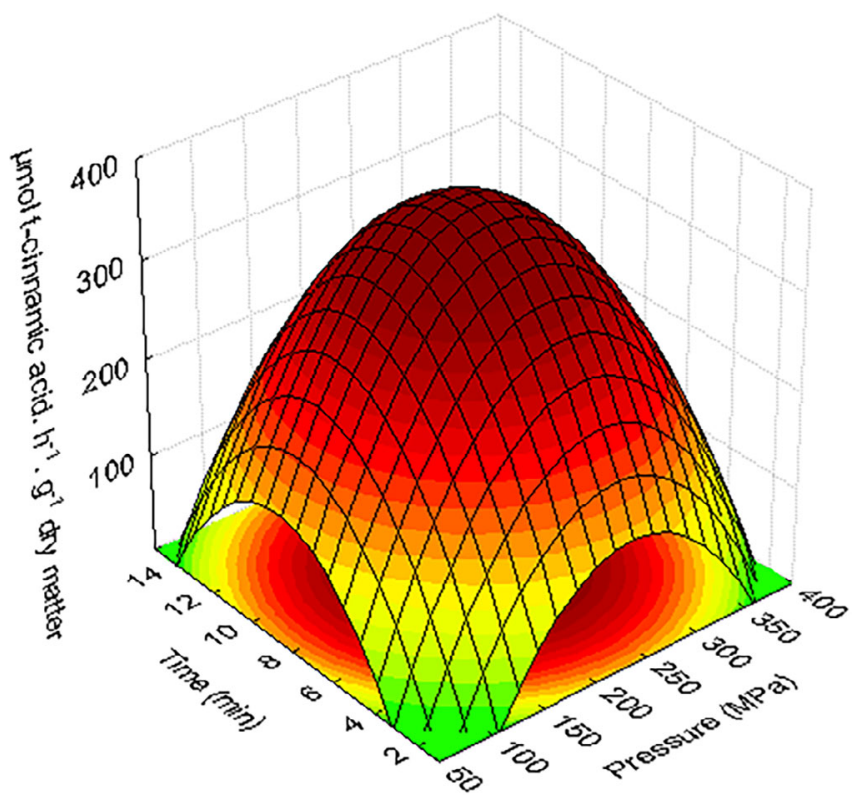

FIGURE 2 Response surfaces fitted for phenylalanine ammonialyase activity $(\mathrm{PAL})$ as a function of pressure $(\mathrm{MPa})$ and time $(\mathrm{min})$ treatment in pineapple shell

and forms a diversity of phenolic compounds with structural and protection-related functions, as well as lignins, phenolic acids, stilbenes, and flavonoids (Chen et al., 2006; Solecka \& Kacperska, 2003).

The increase in TPC with moderate hydrostatic pressure treatment can be explained by an increase in pressure-induced extraction in the pineapple by-product samples, similarly to that observed in pineapple puree (Chakraborty et al., 2016a). High-pressure treatments may also origin variations in enzyme conformation and enzyme substrates, which can facilitate or inhibit enzyme catalyzed reactions (Mozhaev, Lange, Kudryashova, \& Balny, 1996). The rate of enzymatic reactions in the tissue of the plant may increase due to treatments with moderate pressure, since there is rupture of plant tissues and contact between enzyme and substrate (Ludikhuyze, Van Loey, Smout, \& Hendrickx, 2003). 
The synthesis of TPC in plant tissues is related to the enzymatic activity of PAL. The behavior of PAL activity is similar to the behavior of TPC present in fruits, since the decrease in PAL activity caused a decrease in TPC, thus demonstrating the importance of PAL in the promotion of TPC (Zarei, Zamani, Fattahi, Salami, \& Mousavi, 2016).

The main phenolic compounds found to be present in pineapple were gallic acid, catechin, and epicatechin, contributing to a $40 \%$ increase in antioxidant capacity, followed by vitamin $C$ and $\beta$-carotene. Phenolic concentration is related to the increase of PAL enzymatic activity, which is influenced by fruit ripening (Rosas et al., 2018).

\subsection{PPO and PME activity}

In general, the studied variables in experimental conditions do not significantly influence the PPO and PME activities. Obtained models present an insufficient bad fit to the data $\left(R^{2}<0.75\right)$ and a correspondingly significant lack of fit and thus are not presented.

PPO activity values range from 81.24 to $155.71 \mathrm{U} . \mathrm{g}^{-1}$ of dry matter in pineapple shell and 75.80-123.42 U.g $\mathrm{g}^{-1}$ of dry matter in pineapple core. Although the model is not significant, the respective response surface allows observing the trend described in the literature. The use of pressures lower than $100 \mathrm{MPa}$ activates some enzymes, particularly monomeric enzymes such as PPO (Buckow, Weiss, \& Knorr, 2009). In the present study, hydrostatic pressures lower than $100 \mathrm{MPa}$ during less than 8 min increased PPO activity and pressures higher than $300 \mathrm{MPa}$ and treatment times longer than 10 min decrease the activity of this enzyme. The behavior of PPO enzymatic activity under the studied pressure and temperature conditions can be seen as an advantage, since PPO activity is associated with a negative impact on color of fruit products.

PPO showed reduced baroresistance in mixed beverages, like fruit smoothies, when compared to PME. A PME inactivation of $83 \%$ occurred at $700 \mathrm{MPa} / 55^{\circ} \mathrm{C}$ evidencing resistant to pressure in a skim milk-orange juice beverage (Chakraborty, Kaushik, et al., 2014; Keenan, Rößle, Gormley, Butler, \& Brunton, 2012).

The effect of the pressure on enzyme activity depends on the substrate. Moderate hydrostatic pressures (MHP) applied to mushroom increased PPO activity by $140 \%$ after treatment at $400 \mathrm{MPa}$ for $10 \mathrm{~min}$, when compared with the unprocessed sample (Gomes \& Ledward, 1996). Carrot and apple extracts presented an increase in PPO activity after pressure treatments between 100 and $300 \mathrm{MPa}$ for $1 \mathrm{~min}$, which was attributed to the reversible configuration and/ or conformational deviations in enzyme and/or substrate particles (Anese, Nicoli, Dall'aglio, \& Lerici, 1994). The MHP applied in the range $200-500 \mathrm{MPa}$ at room temperature also produced an increase in PPO activity of up to 65\% in apple juice (Buckow et al., 2009).

As for the activity of PAL, the activity of PME points at some activation with increasing pressure, although the model is not significant and thus this cannot be quantified. In the experimental conditions PME's enzymatic activity ranged from 7.71 to $11.76 \mathrm{U} . \mathrm{g}^{-1}$ of dry matter in pineapple shell and 7.99-11.60 U. $\mathrm{g}^{-1}$ of dry matter in pineapple core.
PME was considered a baroresistent enzyme in two studies with pineapple puree, and stability depends on the enzyme origin (Chakraborty, Rao, \& Mishra, 2014; Chakraborty, Rao, \& Mishra, 2019).

The PME has shown evidence of increased activity under MHP in several studies (Eisenmenger \& Reyes-De-Corcuera, 2009). Tomato juice PME was activated by pressures greater than $300 \mathrm{MPa}$ (Hsu, 2008). In the case of carrot assays, PME activity in shredded samples was most evident at $50^{\circ} \mathrm{C}$ and $200-400 \mathrm{MPa}$ and $100-400 \mathrm{MPa}$ at $60^{\circ} \mathrm{C}$ in whole carrots (Sila et al., 2007). PME inactivation rate in carrot samples was reduced (> 75\%) at $300 \mathrm{MPa}$, compared with $100 \mathrm{MPa}$ (Ly-Nguyen et al., 2003). Green peppers subjected to pressure between 100 and $200 \mathrm{MPa}$ showed increased activity of PME after treatment compared with untreated samples (Castro et al., 2008).

\section{5 | Antioxidant activity}

Regarding antioxidant activity of pineapple core samples, the obtained models present an insufficient fit to the data $\left(R^{2}<0.75\right)$ and a correspondingly significant lack of fit and thus they are not presented.

Models obtained for antioxidant activity of pineapple shell samples by DPPH, FRAP and ABTS methods presented a good fit $\left(R^{2}>0.75\right)$ to the data but a significant lack of fit (Table 3 ), so these results will be only considered as indicative of a trend and model figures are not shown.

The moderate pressures studied increase antioxidant activity $85 \%$ by DPPH method, $79 \%$ by FRAP method and $76 \%$ by ABTS method, in the pineapple shell samples (Table 2).

The second order model for the antioxidant activity in pineapple core samples does not fit the data, although there is a trend for activation of antioxidant activity with increasing pressure. The antioxidant activity of the pineapple core samples by the DPPH method ranged between 32.71-43.61 $\mu \mathrm{mol}$ Trolox. $\mathrm{g}^{-1}$ dry matter, the FRAP method ranged between 19.16 and $36.39 \mu \mathrm{mol}$ Trolox. $\mathrm{g}^{-1}$ dry matter and the ABTS method ranged between 29.91 and $51.60 \mu \mathrm{mol}_{\text {Trolox. }}{ }^{-1}$ dry matter.

As a conclusion, intermediate pressures allow an increase of antioxidant activity. Antioxidant activity is also influenced by treatment time, with higher values being obtained for shorter or intermediate studied treatment times.

Other authors have studied the behavior of antioxidant compounds with HPP. The application of high pressure does not reduce antioxidant compounds in the fruit sample but can increase the antioxidant capacity in pineapple (Chakraborty, Rao, \& Mishra, 2015), orange, lemon and carrot mixed juice (Butz et al., 2003), and strawberry and blackberry purees (Patras, Brunton, Da Pieve, \& Butler, 2009).

In another study, Sánchez-Moreno, Plaza, De Ancos, and Cano (2006) observed that, at 50-400 MPa at $25^{\circ} \mathrm{C}$ for $15 \mathrm{~min}$, the antioxidant activity (DPPH) of the aqueous fraction of tomato puree increased. A slight increase in antioxidant activity was observed at pressures of $200 \mathrm{MPa}$ (Sánchez-Moreno, Plaza, De Ancos, \& Cano, 2004).

The explanation for the increase in antioxidant activity may be the increase in extraction yields by hydrostatic pressure treatments. 
Pressure may increase permeability due to the ability to deprotonate charged groups and disrupt salt bridges and hydrophobic bonds in cell membranes (Corrales, Toepfl, Butz, Knorr, \& Tauscher, 2008; Raso \& Barbosa-Cánovas, 2003). The higher amount of TPC and antioxidants may also be influenced by the decrease in water dielectric constant caused by hydrostatic pressure treatments associated with temperature (Fernández, Goodwin, Lemmon, Levelt Sengers, \& Williams, 1997).

Polyphenol content in soluble extracts was significantly higher (17-28\%) compared to other extracts. This increase may result from a rupture of plant cells caused by the treatment of moderate pressures (250-400 MPa and 3-5 min), increasing the extraction capacity of these compounds (Van Eylen, Oey, Hendrickx, \& Van Loey, 2008). Hydrological pressure applied to cashew apple samples (250 MPa for $3 \mathrm{~min}$ ) did not change FRAP measured antioxidant capacity, but the DPPH method presented a $40 \%$ increase in antioxidant capacity (Queiroz et al., 2010). The antioxidant capacity of blackberry puree increased after pressure treatment, but in strawberry puree this effect was not observed (Patras et al., 2009).

\section{6 | Optimization of moderate hydrostatic pressure application conditions}

The desirability function was applied for the simultaneous optimization of the responses that fitted to the second order model for pineapple shell samples (bromelain activity and phenylalanine ammonia-lyase activity) and the desirability surface curves for optimal conditions are shown in Figure 3. The curve allows observing a maximum point that corresponds to the optimal conditions obtained for the results of the models together.

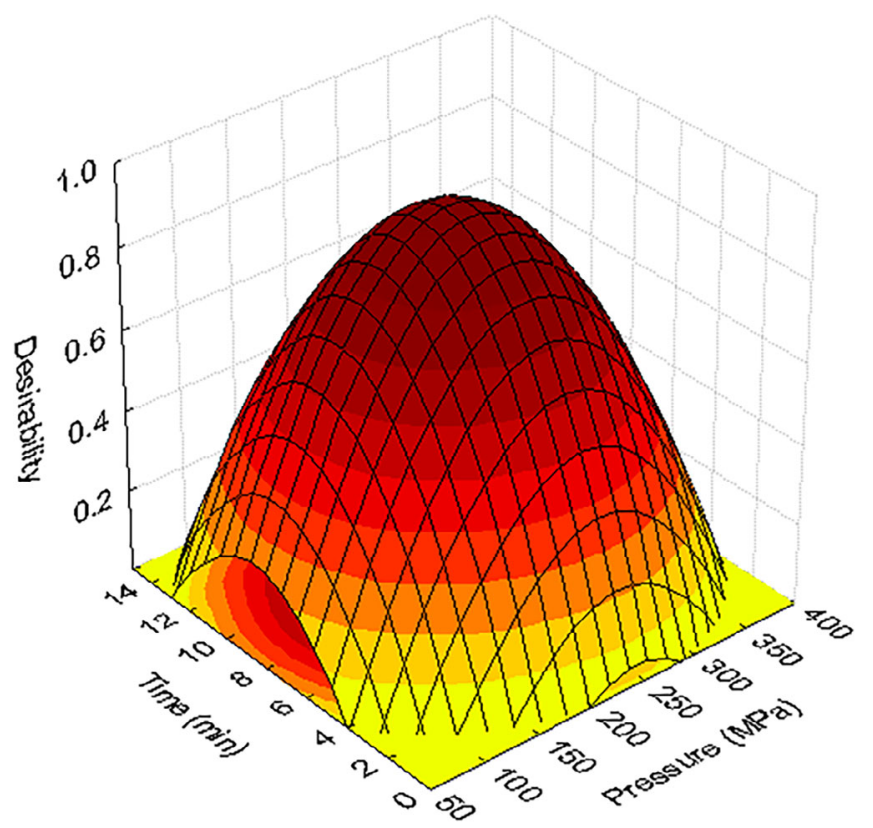

FIGURE 3 Desirability surface curves for optimal conditions as a function of pressure ( $\mathrm{MPa}$ ) and time $(\mathrm{min})$ treatment in pineapple shell for bromelain activity and phenylalanine ammonia-lyase activity (PAL)
The most suitable conditions found for the MHP treatment conditions applied to pineapple shell were $225 \mathrm{MPa}$ during $7.6 \mathrm{~min}$, with desirability values of 0.94 . Under these conditions, the predicted responses for independent studied variables are $28.61 \mu \mathrm{mol}$ tyrosine. $\min ^{-1} \cdot \mathrm{g}^{-1}$ dry matter and $388.48 \mu \mathrm{mol}$ t-cinnamic acid. $\mathrm{h}^{-1} \cdot \mathrm{g}^{-1}$ dry matter for bromelain activity and phenylalanine ammonia-lyase activity, respectively.

In the case of the pineapple core, just the quadratic model generated for bromelain activity was significant in fitting of the experimental data. So, the optimized conditions for bromelain activity will be considered to be $211 \mathrm{MPa}$ of hydrostatic pressure and 8.7 min of treatment time. At these MHP treatment conditions the predicted bromelain activity is $17.71 \mathrm{mg}$ tyrosine. $\mathrm{min}^{-1} \cdot \mathrm{g}^{-1}$ dry matter.

\section{4 | CONCLUSION}

The abiotic stress treatments by moderate hydrostatic pressure promote enzyme activity and induced synthesis of bioactive compounds from pineapple shell and core. The moderate hydrostatic pressure treatments (150-250 MPa) during about 8 min could activate cellular processes as a stress response, enhancing accumulation of bromelain and phenolic compounds with antioxidant activity, whereas more intense hydrostatic pressure treatments (> $300 \mathrm{MPa}$ ) could cause irreversible damage. The increased activity of bromelain is more evident in the pineapple core, while the increase of PAL activity is more perceptible in the pineapple shell.

The results obtained in this work showed that the interesting feature of the pineapple core is bromelain activity and in the pineapple shell it is PAL activity, and consequently TPC. In order to maximize these compounds, it is suggested to apply optimum conditions to maximize bromelain (211 MPa and $8.7 \mathrm{~min}$ ) in the pineapple core and conditions that maximize PAL (221.5 MPa and $8.14 \mathrm{~min}$ ) in the pineapple shell. Pineapple by-products subjected to abiotic stresses may be a good source of bioactive compounds and proteolytic enzymes (bromelain) to be incorporated directly or used in food preparation as a co-product or raw material.

This work thus contributes to valorization of agroindustry wastes, leading to economical (final product with higher added value) and environmental (reduced waste production).

\section{ACKNOWLEDGMENTS}

The authors acknowledge industrial partner Campotec, located in Torres Vedras, Portugal, for supplying the pineapple by-products used in this study.

\section{CONFLICT OF INTEREST}

The authors declare that there is no conflict of interest.

\section{ETHICS STATEMENT}

This article does not contain any studies with human participants or animals performed by any of the authors. 


\section{INFORMED CONSENT}

Not applicable.

\section{ORCID}

Diana I. Santos (iD) https://orcid.org/0000-0001-5177-6878

Carlos A. Pinto (D) https://orcid.org/0000-0002-5742-706X

Luiz C. Corrêa-Filho (D) https://orcid.org/0000-0001-5405-3763

Jorge A. Saraiva (D) https://orcid.org/0000-0002-5536-6056

António A. Vicente (D) https://orcid.org/0000-0003-3593-8878

Margarida Moldão-Martins (D) https://orcid.org/0000-0003-0558-

8715

\section{REFERENCES}

Alegria, C., Gonçalves, E. M., Moldão-Martins, M., Cisneros-Zevallos, L., \& Abreu, M. (2016). Peel removal improves quality without antioxidant loss, through wound-induced phenolic biosynthesis in shredded carrot. Postharvest Biology and Technology, 120, 232-239. https://doi.org/10. 1016/j.postharvbio.2016.07.004

Anese, M., Nicoli, M. C., Dall'aglio, G., \& Lerici, C. R. (1994). Effect of high pressure treatments on peroxidase and polyphenoloxidase activities. Journal of Food Biochemistry, 18(4), 285-293. https://doi.org/10. 1111/j.1745-4514.1994.tb00503.x

Babu, B. R., Rastogi, N. K., \& Raghavarao, K. S. M. S. (2008). Liquid-liquid extraction of bromelain and polyphenol oxidase using aqueous twophase system. Chemical Engineering and Processing: Process Intensification, 47(1), 83-89. https://doi.org/10.1016/j.cep.2007.08.006

Benzie, I. F. F., \& Strain, J. J. (1996). The ferric reducing ability of plasma (FRAP) as a measure of "antioxidant power": The FRAP assay. Analytical Biochemistry, 239(1), 70-76. https://doi.org/10.1006/abio.1996.0292

Bhattacharyya, B. K. (2008). Bromelain: An overview. Natural Product Radiance, 7(4), 359-363.

Brand-Williams, W., Cuvelier, M. E., \& Berset, C. (1995). Use of a free radical method to evaluate antioxidant activity. LWT - Food Science and Technology, 28(1), 25-30. https://doi.org/10.1016/S0023-6438(95) 80008-5

Buckow, R., Weiss, U., \& Knorr, D. (2009). Inactivation kinetics of apple polyphenol oxidase in different pressure-temperature domains. Innovative Food Science and Emerging Technologies, 10(4), 441-448. https://doi.org/10.1016/j.ifset.2009.05.005

Butz, P., Fernández García, A., Lindauer, R., Dieterich, S., Bognár, A., \& Tauscher, B. (2003). Influence of ultra high pressure processing on fruit and vegetable products. Journal of Food Engineering, 56, 233-236. https://doi.org/10.1016/S0260-8774(02)00258-3

Cano, M., \& de Ancos, B. (2005). Advances in use of high pressure to processing and preservation of plant foods. Novel Food Processing Technologies, 283-310. Retrieved from https://www.google.com/ books?hl=pt-PT\&lr=\&id=fpZ1Vpf17JkC\&oi=fnd\&pg=PA283\&dq=Advances +in+use+of+high+pressure+to+processing+and+preservation+of+plant +foods\&ots=1LOpbvSwLp\&sig=7eqHvdPoETvGZYWdT_L2V4hkVjo

Castro, S. M., Saraiva, J. A., Lopes-da-Silva, J. A., Delgadillo, I., Van Loey, A., Smout, C., \& Hendrickx, M. (2008). Effect of thermal blanching and of high pressure treatments on sweet green and red bell pepper fruits (Capsicum annuum L.). Food Chemistry, 107(4), 1436-1449. https://doi.org/10.1016/j.foodchem.2007.09.074

Chakraborty, S., Kaushik, N., Rao, P. S., \& Mishra, H. N. (2014). Highpressure inactivation of enzymes: A review on its recent applications on fruit purees and juices. Comprehensive Reviews in Food Science and Food Safety, 13(4), 578-596. https://doi.org/10.1111/1541-4337. 12071

Chakraborty, S., Rao, P. S., \& Mishra, H. N. (2014). Effect of pH on enzyme inactivation kinetics in high-pressure processed pineapple (Ananas comosus L.) puree using response surface methodology. Food and
Bioprocess Technology, 7(12), 3629-3645. https://doi.org/10.1007/ s11947-014-1380-0

Chakraborty, S., Rao, P. S., \& Mishra, H. N. (2015). Effect of combined high pressure-temperature treatments on color and nutritional quality attributes of pineapple (Ananas comosus L.) puree. Innovative Food Science and Emerging Technologies, 28, 10-21. https://doi.org/10.1016/j.ifset. 2015.01.004

Chakraborty, S., Rao, P. S., \& Mishra, H. N. (2016a). Changes in quality attributes during storage of high-pressure and thermally processed pineapple puree. Food and Bioprocess Technology, 9(5), 768-791. https://doi.org/10.1007/s11947-015-1663-0

Chakraborty, S., Rao, P. S., \& Mishra, H. N. (2016b). Modeling the inactivation kinetics of fruit bromelain in pineapple during high-pressure and thermal treatments. Innovative Food Science and Emerging Technologies, 33, 10-18. https://doi.org/10.1016/j.ifset.2015.12.026

Chakraborty, S., Rao, P. S., \& Mishra, H. N. (2019). Modeling the inactivation of pectin methylesterase in pineapple puree during combined high-pressure and temperature treatments. Innovative Food Science and Emerging Technologies, 52, 271-281. https://doi.org/10.1016/j. ifset.2019.01.008

Chen, J. Y., Wen, P. F., Kong, W. F., Pan, Q. H., Zhan, J. C., Li, J. M., ... Huang, W. D. (2006). Effect of salicylic acid on phenylpropanoids and phenylalanine ammonia-lyase in harvested grape berries. Postharvest Biology and Technology, 40(1), 64-72. https://doi.org/10.1016/j. postharvbio.2005.12.017

Cisneros-Zevallos, L. (2003). The use of controlled postharvest abiotic stresses as a tool for enhancing the nutraceutical content and addingvalue of fresh fruits and vegetables. Journal of Food Science, 68(5), 1560-1565. https://doi.org/10.1111/j.1365-2621.2003.tb12291.x

Corrales, M., Toepfl, S., Butz, P., Knorr, D., \& Tauscher, B. (2008). Extraction of anthocyanins from grape by-products assisted by ultrasonics, high hydrostatic pressure or pulsed electric fields: A comparison. Innovative Food Science and Emerging Technologies, 9(1), 85-91. https://doi. org/10.1016/j.ifset.2007.06.002

Corrêa-Filho, L., Lourenço, S., Duarte, D., Moldão-Martins, M., \& Alves, V. (2019). Microencapsulation of tomato (Solanum lycopersicum L.) pomace ethanolic extract by spray drying: Optimization of process conditions. Applied Sciences, 9(3), 612. https://doi.org/10.3390/app9030612

Eisenmenger, M. J., \& Reyes-De-Corcuera, J. I. (2009). High pressure enhancement of enzymes: A review. Enzyme and Microbial Technology, 45(5), 331-347. https://doi.org/10.1016/j.enzmictec.2009.08.001

Fernández, D. P., Goodwin, A. R. H., Lemmon, E. W., Levelt Sengers, J. M. H., \& Williams, R. C. (1997). A formulation for the static permittivity of water and steam at temperatures from $238 \mathrm{~K}$ to $873 \mathrm{~K}$ at pressures up to $1200 \mathrm{MPa}$, including derivatives and Debye-Hückel coefficients. Journal of Physical and Chemical Reference Data, 26(4), 1125-1166. https://doi.org/10.1063/1.555997

Gomes, M. R. A., \& Ledward, D. A. (1996). Effect of high-pressure treatment on the activity of some polyphenoloxidases. Food Chemistry, 56(1), 1-5. https://doi.org/10.1016/0308-8146(95)00141-7

Haaland, P. D. (1989). Experimental design in biotechnology. In D. B. Owen (Ed.), Statistics: Textbooks and monographs (Vol. 105, p. 259). New York, Basel: Marcel Dekker Inc.

Heredia, J. B., \& Cisneros-Zevallos, L. (2009). The effect of exogenous ethylene and methyl jasmonate on pal activity, phenolic profiles and antioxidant capacity of carrots (Daucus carota) under different wounding intensities. Postharvest Biology and Technology, 51(2), 242-249. https://doi.org/10.1016/j.postharvbio.2008.07.001

Hsu, K. C. (2008). Evaluation of processing qualities of tomato juice induced by thermal and pressure processing. LWT - Food Science and Technology, 41(3), 450-459. https://doi.org/10.1016/j.lwt.2007.03.022

Jacobo-Velázquez, D. A., \& Hernández-Brenes, C. (2010). Biochemical changes during the storage of high hydrostatic pressure processed avocado paste. Journal of Food Science, 75(6), S264-S270. https://doi. org/10.1111/j.1750-3841.2010.01654.x 
Jacobo-Velázquez, D. A., González-Agüero, M., \& Cisneros-Zevallos, L. (2015). Cross-talk between signaling pathways: The link between plant secondary metabolite production and wounding stress response. Scientific Reports, 5(1), 8608. https://doi.org/10.1038/srep08608

Keenan, D. F., Rößle, C., Gormley, R., Butler, F., \& Brunton, N. P. (2012). Effect of high hydrostatic pressure and thermal processing on the nutritional quality and enzyme activity of fruit smoothies. LWT - Food Science and Technology, 45(1), 50-57. https://doi.org/10.1016/j.lwt.2011.07.006

Ludikhuyze, L., Van Loey, A., Indrawati Smout, C., \& Hendrickx, M. (2003). Effects of combined pressure and temperature on enzymes related to quality of fruits and vegetables: From kinetic information to process engineering aspects. Critical Reviews in Food Science and Nutrition, 43(5), 527-586. https://doi.org/10.1080/10408690390246350

Ly-Nguyen, B., Van Loey, A. M., Smout, C., Özcan, S. E., Fachin, D., Verlent, I., ... Hendrickx, M. E. (2003). Mild-heat and high-pressure inactivation of carrot pectin methylesterase: A kinetic study. Journal of Food Science, 68(4), 1377-1383. https://doi.org/10.1111/j.13652621.2003.tb09653.x

Montgomery, D. C. (2017). Design and analysis of experiments (9th ed.). Hoboken, NJ, USA: John Wiley \& Sons, Inc. Retrieved from https:// books.google.pt/books?hl=pt-PT\&lr=\&id=Py7bDgAAQBAJ\&oi=fnd\& pg=PA1\&ots=X6v_q_JS23\&sig=1EU_hb8OZ5e13ldWgWIOzZXg8E4\& redir_esc $=\mathrm{y} \# \mathrm{v}=$ onepage $\& q \& \mathrm{f}=$ false

Mozhaev, V. V., Lange, R., Kudryashova, E. V., \& Balny, C. (1996). Application of high hydrostatic pressure for increasing activity and stability of enzymes. Biotechnology and Bioengineering, 52(2), 320-331. https:// doi.org/10.1002/(SICI)1097-0290(19961020)52:2<320::AID-BIT12> 3.0.CO;2-N

Orozco-Cardenas, M. L., Narvaez-Vasquez, J., \& Ryan, C. A. (2001). Hydrogen peroxide acts as a second messenger for the induction of defense genes in tomato plants in response to wounding, Systemin, and methyl Jasmonate. The Plant Cell, 13(1), 179-191. https://doi.org/10.2307/ 3871162

Patras, A., Brunton, N. P., Da Pieve, S., \& Butler, F. (2009). Impact of high pressure processing on total antioxidant activity, phenolic, ascorbic acid, anthocyanin content and colour of strawberry and blackberry purées. Innovative Food Science and Emerging Technologies, 10(3), 308-313. https://doi.org/10.1016/j.ifset.2008.12.004

Pavan, R., Jain, S., Shraddha, \& Kumar, A. (2012). Properties and therapeutic application of bromelain: A review. Biotechnology Research International, 2012, 1-6. https://doi.org/10.1155/2012/976203

Pinheiro, J., Silva, C. L. M., Alegria, C., Abreu, M., \& Gonçalves, E. M. (2012). Optimization, heat stability and kinetic characterization of pectin-methylesterase enzyme from tomato ('Zinac') Fruitssolanum lycopersicum. Acta Horticulturae, 934, 1283-1290.

Queiroz, C., Moreira, C. F. F., Lavinas, F. C., Lopes, M. L. M., Fialho, E., \& Valente-Mesquita, V. L. (2010). Effect of high hydrostatic pressure on phenolic compounds, ascorbic acid and antioxidant activity in cashew apple juice. High Pressure Research, 30(4), 507-513. https://doi.org/ 10.1080/08957959.2010.530598

Raimbault, A.-K., Zuily-Fodil, Y., Soler, A., Mora, P., \& Cruz de Carvalho, M. H. (2013). The expression patterns of bromelain and AcCYS1 correlate with blackheart resistance in pineapple fruits submitted to postharvest chilling stress. Journal of Plant Physiology, 170(16), 1442-1446. https://doi.org/10.1016/j.jplph.2013.05.008

Raso, J., \& Barbosa-Cánovas, G. V. (2003). Nonthermal preservation of foods using combined processing techniques. Critical Reviews in Food Science and Nutrition, 43(3), 265-285. https://doi.org/10.1080/ 10408690390826527

Re, R., Pellegrini, N., Proteggente, A., Pannala, A., Yang, M., \& Rice-Evans, C. (1999). Antioxidant activity applying an improved ABTS radical cation decolorization assay. Free Radical Biology and Medicine, 26(9-10), 1231-1237. https://doi.org/10.1016/S0891-5849(98)00315-3

Rosas, C., Domínguez, J., Pareek, S., Villegas, M., Ayala, F., Yahia, E., \& González, G. (2018). Content of bioactive compounds and their contribution to antioxidant capacity during ripening of pineapple (Ananas comosus L.) cv. Esmeralda. Journal of Applied Botany and Food Quality, 91, 61-68. https://doi.org/10.5073/JABFQ.2018.091.009

Rufino, M. S. M., Alves, R. E., Sousa De Brito, E., Maia De Morais, S., Goes Sampaio, C., Pérez-Jiménez, J., \& Saura-Calixto, F. D. (2007). Metodologia Científica: Determinação da Atividade Antioxidante Total em Frutas pela Captura do Radical Livre ABTS +. Brazil. Retrieved from Comunicado Técnico (Embrapa Agroindústria Tropical). http://www. cnpat.embrapa.br/cnpat/down/index.php?pub/Cot_128.pdf

Sánchez-Moreno, C., Plaza, L., De Ancos, B., \& Cano, M. P. (2004). Effect of combined treatments of high-pressure and natural additives on carotenoid extractability and antioxidant activity of tomato puree (Lycopersicum esculentum mill.). European Food Research and Technology, 219(2), 151-160. https://doi.org/10.1007/s00217-004-0926-1

Sánchez-Moreno, C., Plaza, L., De Ancos, B., \& Cano, M. P. (2006). Impact of high-pressure and traditional thermal processing of tomato purée on carotenoids, vitamin $\mathrm{C}$ and antioxidant activity. Journal of the Science of Food and Agriculture, 86(2), 171-179. https://doi.org/10.1002/jsfa.2321

Sila, D. N., Smout, C., Satara, Y., Truong, V., Van Loey, A., \& Hendrickx, M. (2007). Combined thermal and high pressure effect on carrot pectinmethylesterase stability and catalytic activity. Journal of Food Engineering, 78(3), 755-764. https://doi.org/10.1016/j.jfoodeng.2005.11.016

Solecka, D., \& Kacperska, A. (2003). Phenylpropanoid deficiency affects the course of plant acclimation to cold. Physiologia Plantarum, 119(2), 253-262. https://doi.org/10.1034/j.1399-3054.2003.00181.x

Surjadinata, B. B., \& Cisneros-Zevallos, L. (2012). Biosynthesis of phenolic antioxidants in carrot tissue increases with wounding intensity. Food Chemistry, 134(2), 615-624. https://doi.org/10.1016/j.foodchem.2012.01.097

Swain, T., \& Hillis, W. E. (1959). The phenolic constituents of Prunus domestica. I.-The quantitative analysis of phenolic constituents. Journal of the Science of Food and Agriculture, 10(1), 63-68. https://doi.org/10. 1002/jsfa.2740100110

Terefe, N. S., Buckow, R., \& Versteeg, C. (2014, January 4). Quality-related enzymes in fruit and vegetable products: Effects of novel food processing technologies, part 1: High-pressure processing. Critical Reviews in Food Science and Nutrition, 54, 24-63. https://doi.org/10. 1080/10408398.2011.566946

Tomás-Barberán, F. A., \& Espín, J. C. (2001). Phenolic compounds and related enzymes as determinants of quality in fruits and vegetables. Journal of the Science of Food and Agriculture, 81, 853-876. https:// doi.org/10.1002/jsfa.885

Van Eylen, D., Oey, I., Hendrickx, M., \& Van Loey, A. (2008). Effects of pressure/temperature treatments on stability and activity of endogenous broccoli (Brassica oleracea L. cv. Italica) myrosinase and on cell permeability. Journal of Food Engineering, 89(2), 178-186. https://doi. org/10.1016/j.jfoodeng.2008.04.016

Zarei, A., Zamani, Z., Fattahi, R., Salami, A., \& Mousavi, A. (2016). Analysis of the phenylpropanoid enzyme activities and products in the softand hard-seeded pomegranate genotypes during fruit development. International Journal of Fruit Science, 16(3), 242-258. https://doi.org/ 10.1080/15538362.2015.1089814

Zhou, Y., Dahler, J. M., Underhill, S. J., \& Wills, R. B. (2003). Enzymes associated with blackheart development in pineapple fruit. Food Chemistry, 80(4), 565-572. https://doi.org/10.1016/S0308-8146(02)00375-8

How to cite this article: Santos DI, Pinto CA, Corrêa-Filho LC, Saraiva JA, Vicente AA, Moldão-Martins M. Effect of moderate hydrostatic pressures on the enzymatic activity and bioactive composition of pineapple by-products. J Food Process Eng. 2020;e13537. https://doi.org/10.1111/jfpe. 13537 